NASA Technical Memorandum 102366

\title{
The Fuel Cell in Space: Yesterday, Today and Tomorrow
}

Marvin Warshay and Paul R. Prokopius

Lewis Research Center

Cleveland, Ohio

Prepared for the Grove Anniversary (1839-1989) Fuel Cell Symposium sponsored by the Royal Institution London, Great Britain, September 18-21, 1989

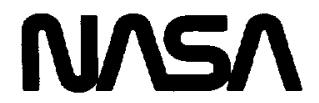

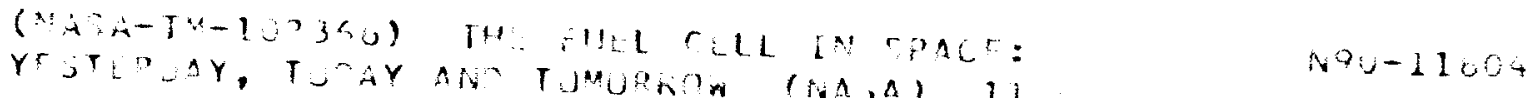

$$
\begin{aligned}
& \text { 2. } 110^{\circ}
\end{aligned}
$$

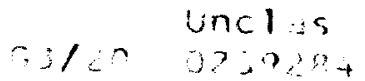


THE FUEL CELL IN SPACE: YESTERDAY, TODAY AND TOMORROW

Marvin Warshay and Paul R. Prokopius

National Aeronautics Space Administration

Lewis Research Center

Cleveland, Ohio 44135

\section{SUMMARY}

The past, present, and future of space fuel cell power systems is reviewed, starting with the first practical fuel cell by $F$.T. Bacon which led to the $1.5 \mathrm{~kW}$ Apollo alkaline fuel cell. However, the first fuel cell to be used for space power was the Gemini $1.0 \mathrm{~kW}$ acid IEM fuel cell.

The successor to the Apollo fuel cell is today's $12 \mathrm{~kW}$ Orbiter alkaline fuel cell whose technology is considerably different and considerably better than that of its ancestor, the Bacon cell. And in terms of specific weight there has been a steady improvement from the past to the present, from the close to $200 \mathrm{lb} / \mathrm{kW}$ of Apollo to the $20 \mathrm{lb} / \mathrm{kW}$ of the orbiter.

For NASA future Lunar and Martian surface power requirements the regenerative fuel cell (RFC) energy storage system is enabling technology, with the alkaline and the PEM the leading RFC candidate systems. The U.S. Air Force continues to support fuel cell high power density technology development for its future short-duration applications.

\section{INTRODUCTION}

The first practical fuel cell resulted from work begun in England in 1932 by F.T. Bacon. Eventually a $5 \mathrm{~kW}$ hydrogen-oxygen, alkaline electrolyte system developed by Bacon demonstrated its capability by powering a welding machine, a circular saw, and a 2-ton fork lift truck. With these and other demonstrations of the applications of this "new" power device, the fuel cell had finally apparently emerged from the laboratory. However, it was the worldwide attention to NASA space missions that introduced "fuel cell" to the vocabulary of millions of people. Ironically, it has probably been the announcement, during space flights, of real or suspected fuel cell malfunctions, rather than the usual smooth performance of the fuel cells in space, that has given fuel cells their wide recognition. (The aborted Apollo $13 \mathrm{flight}$ was a case in point. A prelaunch malfunction of an oxygen feed control component - not the proclaimed fuel cell problem - was the real cause of the near disaster that attracted the attention of many millions of people.)

\section{THE PAST}

In the early years of U.S. space flight, the fuel cell was selected over other competing power systems because of its greater promise to meet the on-board power requirements of planned NASA extended duration manned missions. In addition to satisfying the power, efficiency, weight, life, reliability, 
safety, mission flexibility, development maturity, etc. requirements, the fuel cell offered a number of special advantages over competing power systems.

Noteworthy among these advantages was the ability of the hydrogen-oxygen fuel cell to supply potable water (the product of the electrochemical reaction) for crew consumption and for cabin air humidification.

What emerged as a result of the NASA selection of the fuel cell was an almost explosive growth in fuel cell research and development (primarily sponsored by NASA and other U.S. government organizations) in industries, in universities, and in government laboratories.

For the Gemini earth-orbiting mission (1962 to 1965) fuel cells were successful in supplying power in a reliable manner. The General Electric (GE) fuel cells that were used for seven fights of that mission utilized solid polymer electrolytes (called an ion-exchange membrane (IEM) at that time) consisting of a cationic membrane of sulfonated polystyrene resin. This type of electrolyte had mobile $\mathrm{H}^{+}$ions in well-defined electrolyte boundaries. The advantage of the obvious ease of electrolyte containment was offset by the ohmic resistance of the membrane, which contributed to the lower performance (voltage efficiency) of the IEM than of alkaline fuel cell systems such as that used for the Apollo missions that followed. Making the membrane thin minimized, as much as possible, the effect of high ohmic resistance. (In the 1980's there has been considerable improvement in the performance of this concept, now called the Proton Exchange Membrane, or PEM. This is discussed in "The Future" section.)

The Gemini $1 \mathrm{~kW}$ powerplant consisted of three stacks of 32 cells. The heat generated by the fuel cell stack was removed by a circulating coolant. Two $1-k W$ powerplants were on board to handle maximum load requirements. The average power that was produced on the Gemini flights was $620 \mathrm{~W}$. The hydrogen and oxygen reactants were stored in their cryogenic states. The nominal hydrogen supply pressure was 1.7 psi above water pressure, that of the oxygen 0.5 ps $i$ above the hydrogen pressure. The cell operating temperature was $70^{\circ} \mathrm{F}$. The anode and cathode consisted of titanium screens upon which unsupported $\mathrm{Pt}$ catalysts with PTFE were deposited. The catalyst loading was $28 \mathrm{mg} \mathrm{Pt} / \mathrm{cm}^{2}$ / electrode. This IEM fuel cell technology was subsequently (1967) used for the Biosatellite spacecraft. An important change in the IEM fuel cell technology for this application was the use of a new membrane, namely the perfluorosulfonic acid ionomer. The membrane called Nafion (registered trademark) was developed by DuPont. These type of cationic membranes became the standard for this type of fuel cell, which continues to this day.

A special problem of the Gemini IEM fuel cell was its sensitivity to membrane water content. With insufficient water the membrane would dry out and often crack. On the other hand, the membrane could not hold too much water. A flooded electrode was often the result. Both extremes would result in a severe performance loss. To avoid the problem of excess water, the Gemini fuel cell design utilized wicks to carry excess water to a ceramic porous separator where the water was separated from the oxygen and sent to an accumulator for storage.

The fuel cell technology that went to the moon was not based upon the Gemini IEM fuel cell of the 1960's, but rather upon the Bacon cell that preceded 
the GE/IEM fuel cell work. Through the British National Research and Development Council and Leesona-Moos Laboratories, Pratt \& Whitney acquired the patent to Bacon's fuel cell technology in 1959 and applied the technology to the NASA Apollo mission. However, for space use, the heavy, high pressure Bacon cell was not directly suitable. For the Apollo fuel cell, the pressure was lowered from 600 to $50 \mathrm{psi}$. To prevent the $\mathrm{KOH}$ from boiling at $205{ }^{\circ} \mathrm{C}$, the $\mathrm{KOH}$ concentration was increased from 30 to 75 percent. But, at ambient temperature 75 percent $\mathrm{KOH}$ is solid. However, this proved not to be a significant problem. Finally, the temperature was raised to $260{ }^{\circ} \mathrm{C}$ to recover the performance lost by the pressure reduction. The Apollo fuel cell included Bacon's double-porosity layer nickel electrodes designed to maintain the gas-electrolyte interface at the boundary between the pore size regions. The anode was porous nickel while the cathode was lithiated, oxidized porous nickel. Because of the high temperature (maximum) of $260^{\circ} \mathrm{C}$ a highly active catalyst like Pt was not needed as can the case of the Gemini fuel cell which operated at $70^{\circ} \mathrm{F}$. At $260{ }^{\circ} \mathrm{C}$ and a current density of $150 \mathrm{~A} / \mathrm{ft}^{2}$ the voltage was $0.87 \mathrm{~V} / \mathrm{celll}$, while at its nominal operating temperature of $204{ }^{\circ} \mathrm{C}$ it produced $0.72 \mathrm{~V}$ at $150 \mathrm{~A} / \mathrm{ft}^{2}$. The performance of the Gemini fuel cell was lower.

The Apollo fuel cell $1.5 \mathrm{~kW}$ powerplant consisted of three modules connected electrically in parallel. Heat and water removal were by hydrogen circulation. A glycol-water secondary coolant loop was also employed. The power range was 563 to $1420 \mathrm{~W}$. Peak power capability was $2295 \mathrm{~W}$ at $20.5 \mathrm{~V}$. It weighed $220 \mathrm{lb}$. The module rating was $400 \mathrm{hr}$; but it ran $690 \mathrm{hr}$ without failing. The Apollo missions were from 1968 to 1972.

The $\mathrm{KOH}-\mathrm{H}_{2} \mathrm{O}$ electrolyte solution was pressurized to $53.5 \mathrm{psia}$ while each reactant gas cavity was maintained at 63 psia. The operating pressure of the system and relative pressure differentials affected the fuel cell performance. The latter determined the location of the reactant-electrolyte interface.

\section{PRESENT}

Bacon might not recognize the "grandchild" of his alkaline fuel cell today, the Orbiter fuel cell. The high pressure, very heavy construction of Bacon's fuel cell was already gone in the Apollo fuel cell. In the Orbiter fuel cell, United Technologies Corp. (the new name for the Pratt \& Whitney fuel cell organization) dropped the dual porosity electrodes. In the place of free electrolyte, the Orbitor electrolyte held the 32 percent $\mathrm{KOH}$ electrolyte in an asbestos matrix. Another change was the cell temperature, which was reduced to $93{ }^{\circ} \mathrm{C}$. At this temperature an electrocatalyst was required to achieve a reasonable performance. The operating pressure is 60 psia. The electrodes consisted of goid plated $\mathrm{Ni}$ screens upon which a catalyst layer and PTFE was applied. The hydrophobic PTFE provided gas passages through the electrode. The catalyst loading on each electrode is $20 \mathrm{mg} / \mathrm{cm}^{2}$ Au Pt alloy on the cathode and $10 \mathrm{mg} / \mathrm{cm}^{2} \mathrm{Pt}$ on the anode.

Heat generated by the fuel cell reaction is transferred to the fuel cell's coolant system. The fuel cell coolant system, containing a fluorinated hydrocarbon dielectric liquid, transfers the heat through the Orbiter's heat exchangers to the freon coolant system. 
The Space Shuttle Orbiter is equipped with three fuel cell powerplants supplying $12 \mathrm{~kW}$ at peak and $7 \mathrm{~kW}$ average power. Each powerplant weighs $2501 \mathrm{~b}$. The Orbiter's fuel cell powerplants are $501 \mathrm{~b}$ lighter and deliver up to 8 times as much power as those of Apollo.

The fuel cell powerplants are started approximately $8 \mathrm{hr}$ prior to launch, using ground-supplied hydrogen and oxygen reactants. Approximately $7 \mathrm{~min}$ is required to bring the powerplants to full operating capacity. After startup, the fuel cells share spacecraft electrical loads with ground power support. About 3 min prior to launch, the spacecraft automatically switches to onboard reactant supply and the fuel cells become the sole source of electrical power for the spacecraft for the duration of the mission. Approximately every $8 \mathrm{hr}$ during the mission each fuel cell powerplant is ourged for $2 \mathrm{~min}$ to remove inert gases from the system.

\section{THE FUTURE}

NASA's planning for the future exploration of the Solar system includes the establishment of manned outposts, as well as central base stations on the Moon and Mars. Supporting human expeditions to, and operations on, the surface of the Moon or Mars represents a substantial technology challenge for current and projected power system capabilities. The high levels of power associated with an operational base, somewhere in the 100 to $1000 \mathrm{~kW}$, will require nuclear power systems. During the installation of these permanent nuclear systems, power systems based on solar energy hold the greatest promise for supplying needed power. These systems will also be required to augment and serve as back-up power sources for the permanent nuclear-powered bases.

Because the solar-based surface power system must supply usable power continuously, that is during the day as well as the night, a regenerative system is required. During the daylight hours the power generation subsystem will recharge the energy storage subsystem and also supply power directly to the system's electrical loads. Thus, continuous power is supplied to the load; it is provided by the power generation subsystem during sun periods and from the energy storage subsystem during periods of darkness.

In a Lunar application, the period of darkness extends for 2 weeks, while a Mars application presents a more manageable 12-hr night. Both applications require very high energy density and reliable energy storage systems. The highest potential for successfully achieving surface power storage capabilities for these appiications lies in the regenerative fuel cell (RFC) concept. The regenerative fuel cell system is depicted in figure 1. During the light portion of the orbit the photovoltaic solar arrays generate sufficient power to service the system electrical loads plus a water electrolysis unit. The amount of electrical energy required by the electrolysis unit is dictated by the amount of hydrogen and oxygen needed to generate power in a fuel cell, which supplies the electrical loads during the dark portion of the orbit. In generating this power, water is produced by the fuel cell as a by-product of the electrochemical reaction. To complete the cycle, the by-product water is collected and stored for use in the electrolyzer during the succeeding orbit.

The mass and specific energy benefits to be realized by employing a regenerative fuel cell system are displayed in figure 2 . Low system mass for a 
given power level is a central requirement for achieving acceptance of transportation costs to the Moon or Mars. Another requirement, even more challenging, is appreciable system lifetime without sacrificing performance even after an extended period of dormancy. Also a relatively high power level requirement of $25 \mathrm{~kW}$ is projected to support an initial surface outpost of four to six astronauts. To develop the technology base for a system which will meet these requirements, a program has been initiated as one of the elements of NASA Project Pathfinder. This program was developed and is being managed by NASA Lewis Research Center. It focuses on the technology areas of solar power generation, energy storage and electrical power management. Advancing these technologies and coupling their performance potentials with an advanced low mass, reliable electrical power management subsystem can lead to surface power systems having a reliable life in excess of $20000 \mathrm{hr}$ with system specific powers of $3 \mathrm{~W} / \mathrm{kg}$ for Lunar application and $8 \mathrm{~W} / \mathrm{kg}$ for Martian applications. These projected specific powers represent substantial improvements over the state-ofthe-art, up to a factor of 30 . System mass reductions of this magnitude, coupled to the expected factor of 10 increase in life, should enable extraterrestrial surface missions where life and mass are the driving forces for success.

The Energy Storage element of the Pathfinder Surface Power Program is a 10-year effort culminating in the verification of a regenerative fuel cell system breadboard operating in a relevant environment. The near-term, 5-year, Phase I effort, will provide the development and verification of the system critical components, those being the fuel cell and electrolyzer stacks. The second 5-year phase will focus on the development and verification of the complete RFC breadboard system.

The two candidate fuel cell and electrolyer technologies for the Pathfinder system are the alkaline and proton exchange membrane (PEM). Because alkaline was the system of choice for both Apollo and the Space Shuttle, the state-of-the-art of alkaline systems had been advanced considerabiy over that of the PEM technology. However, the recent technology efforts on fuel cells for transportation applications have advanced the PEM technology.

The major deficiency facing the alkaline technology in the Pathfinder application is the lack of long term catalyst layer stability, which translates into performance degradation with time. Unlike with PEM and other acid-type fuel cells, a stabilizing catalyst support has not been developed for the alkaline system. PEM, on the other hand, offers a stable, long life system but one whose efficiency has, until recently, been significantly lower than alkaline. Recent improvements in the conductivity of PEM membranes increase the probability that this technology could replace alkaline as the Pathfinder RFC baseline. At present, the weakness in the PEM technology stems from the fact that the membrane technology improvements are very recent and, therefore, the data base needed to justify committment to this technology does not exist. Accordingly, a technology assessment has been undertaken to provide guidelines for selecting the technology to be carried into full development in the Pathfinder Program.

Since the late 1960's the U.S. Air Force has been supporting fuel cell technology development for future space applications requiring very high power densities for much shorter periods than for NASA missions. Figure 3 illustrates the steady progress over the years in alkaline fuel cell power density 
performance improvement. The work was carried out by UTC (this part of UTC is now called the International Fuel Cells Corp., IFC).

The Solid Oxide Fuel Cell (SOFC) in its monolith configuration has the potential for even higher power density performance than does the alkaline fuel cell system. However, the high power density alkaline fuel cell system is much further along in its development than is the SOFC for the Air Force Space applications. The government funding for the SOFC monolith concept has been directed at the NASP (National Aerospace Plane) application. Finally, the alkaline fuel cell system holds particular promise for the proposed National Space Transportation System (NSTS), sometimes referred to as the all-electric shuttle. Here the fuel cell is to supply both on-board power and high power density, short burst power for electrical control system accuators.

The European space program also plans to use fuel cell systems to satisfy spacecraft power requirements. Hermes, the European manned reusable space plane will require 3 to $4 \mathrm{~kW}$ for low earth orbit missions. Its electrical system will utilize fuel cells as the primary power source and lithium primary batteries as a back-up/peak power supply (peak of $15 \mathrm{~kW}$ ). For future European spacecraft high power requirements, European organizations have been studying RFC systems.

\section{CONCLUDING REMARKS}

Figure 4 is a graphic depiction of the progress in space fuel cell power, as well as the hope for the future in particular applications. (However, this figure does not depict the progress leading to the important future NASA space fuel cell application discussed in this paper, namely the RFC for Lunar and Mars surface power energy storage.) In terms of specific weight it illustrates the steady improvement from the past to the present, from the close to $200 \mathrm{lb} / \mathrm{kW}$ of the Apollo $1.5 \mathrm{~kW}$ powerplant to the $201 \mathrm{~b} / \mathrm{kW}$ of the Orbiter $12 \mathrm{~kW}$ fuel cell powerplant of today. Based on technology development both underway and planned, it forecasts meeting the goals of (1) about $1.5 \mathrm{lb} / \mathrm{kW}$, in about 1993, for the $300 \mathrm{~kW}$ NSTS fuel cell powerplant, and (2) about $0.5 \mathrm{lb} / \mathrm{kW}$ for the very high power density, short duration applications at the beginning of the 21 st century. 


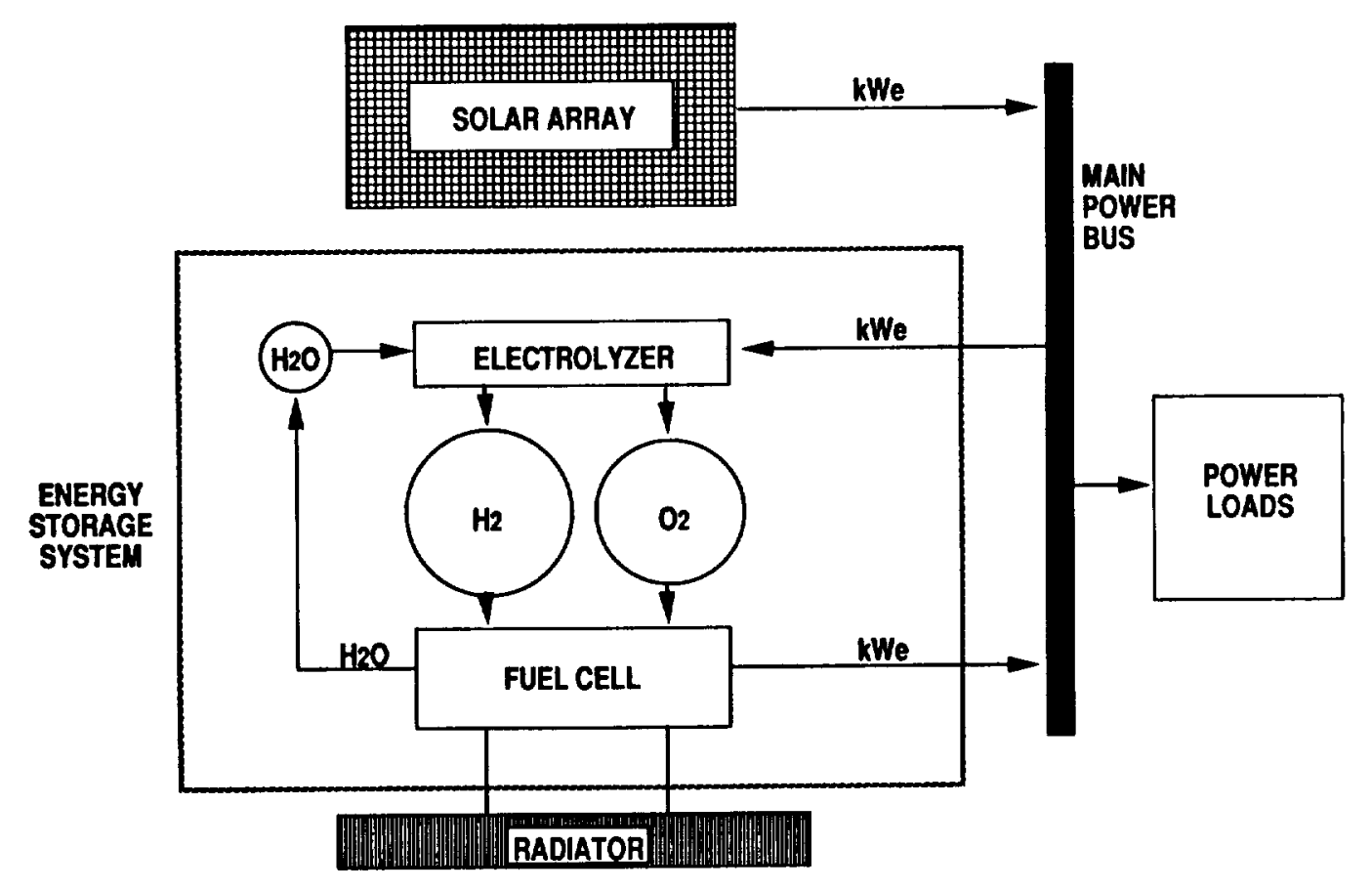

FIGURE 1: REGENERATIVE FUEL CELL SYSTEM SCHEMATIC 
SPECIFIC ENERGY OF 25 kWe ENERGY STORAGE SYSTEM
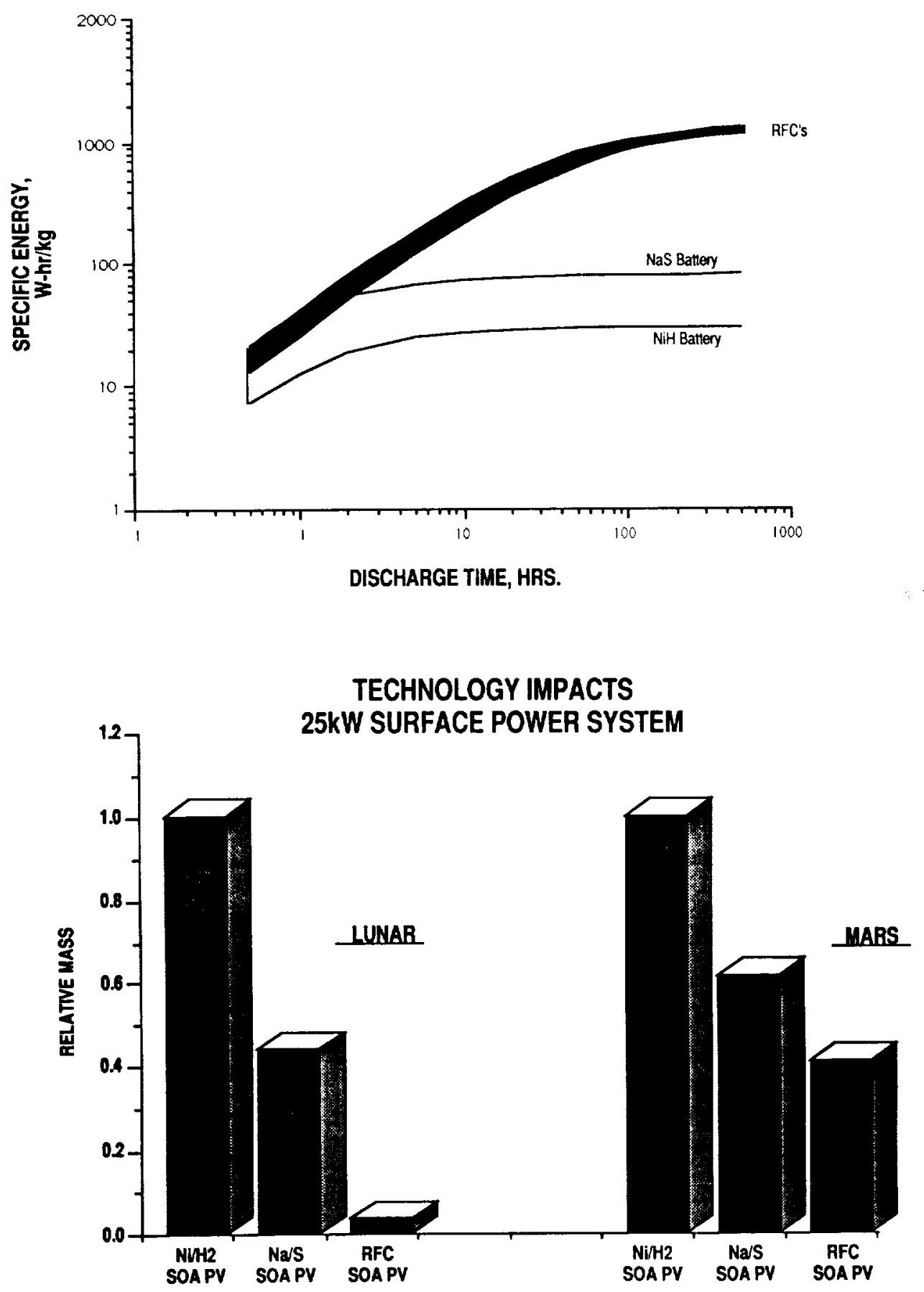

FIGURE 2: ADVANTAGES OF REGENERATIVE FUEL CELL ENERGY STORAGE VERSUS BATTERY SYSTEMS FOR LONG DISCHARGE APPLICATIONS 


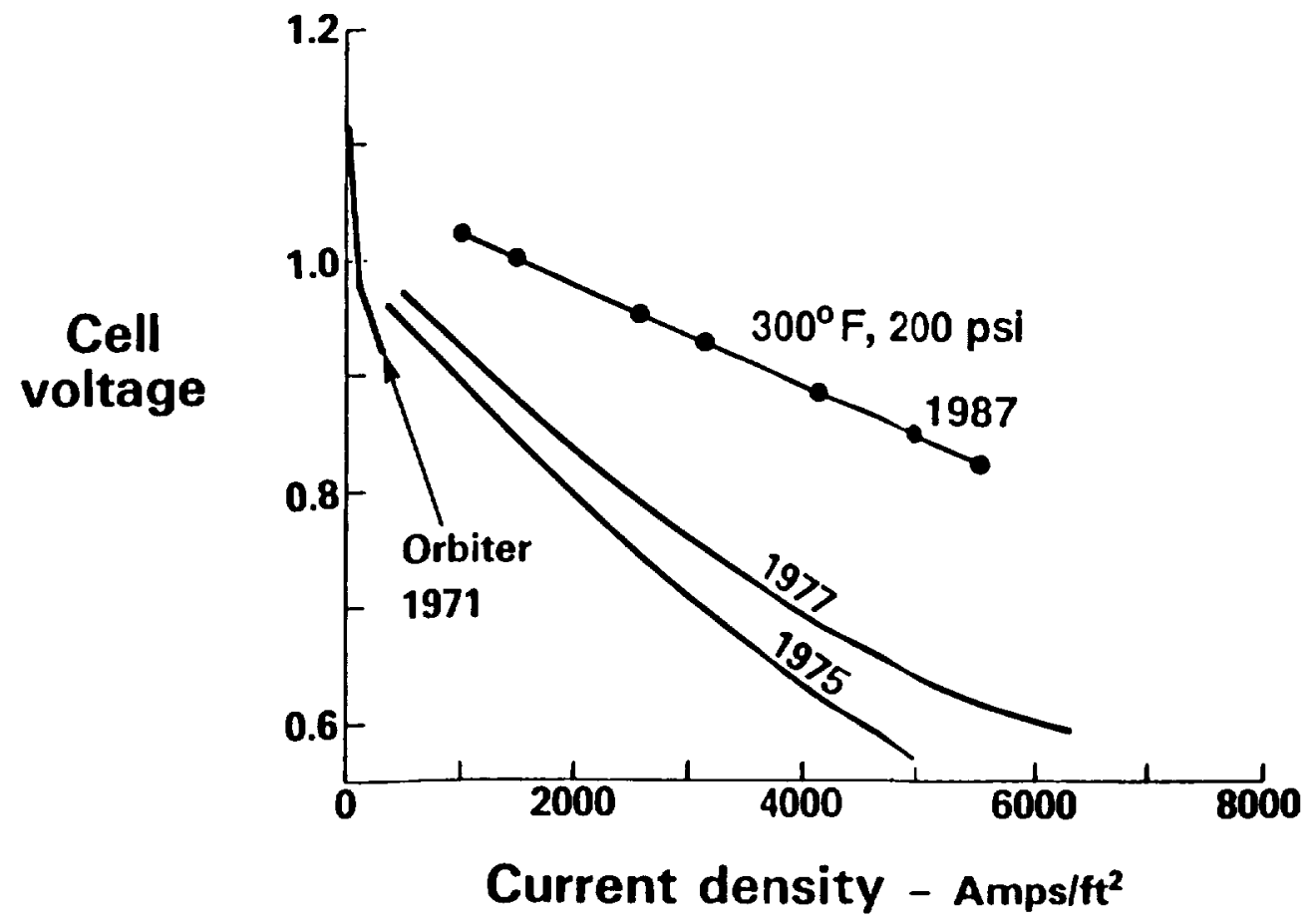

FIGURE 3: ALKALINE HIGH POWER DENSITY PERFORMANCE

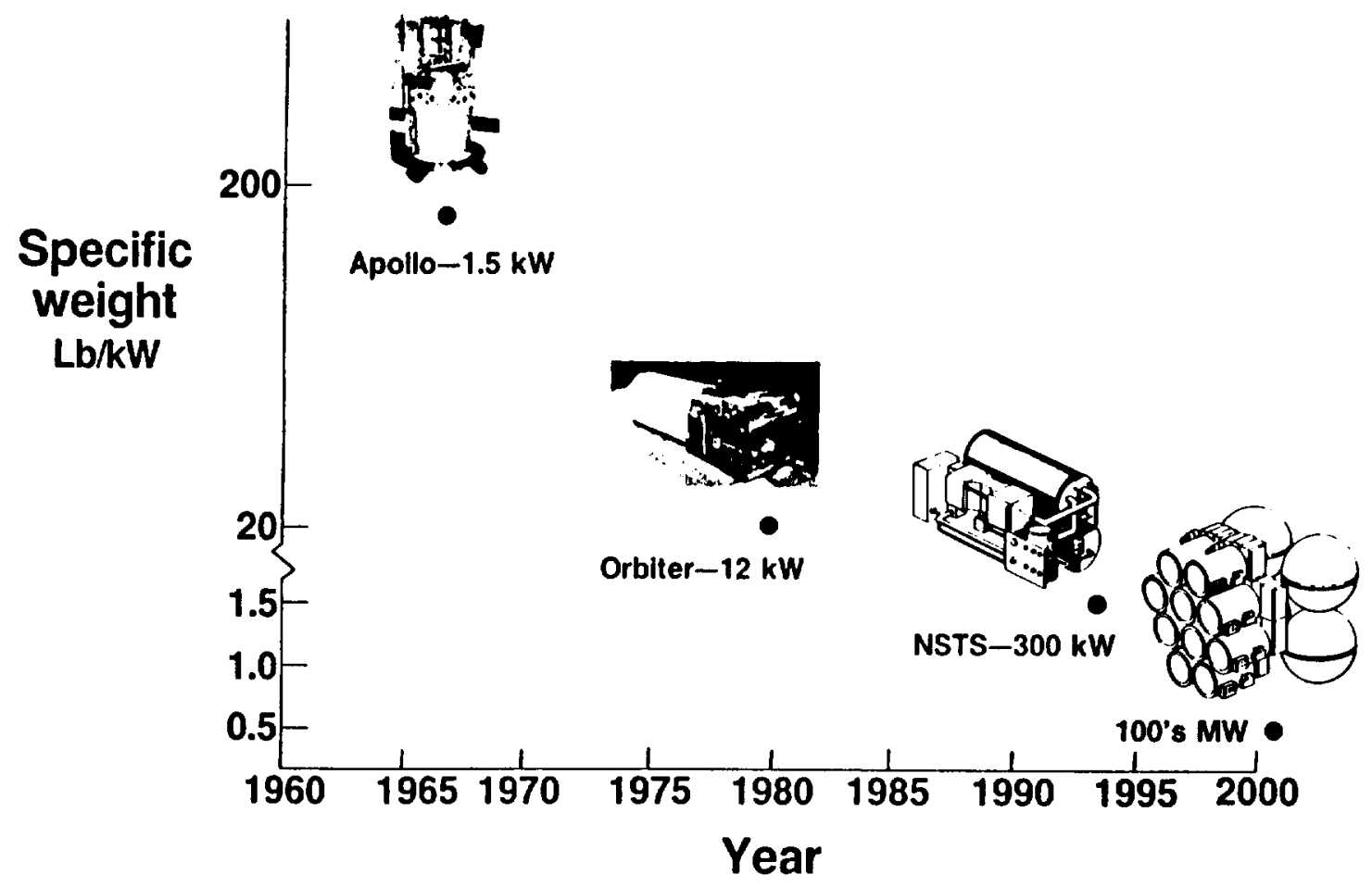

FIGURE 4: PROGRESS IN FUEL CELL SPACE POWER 


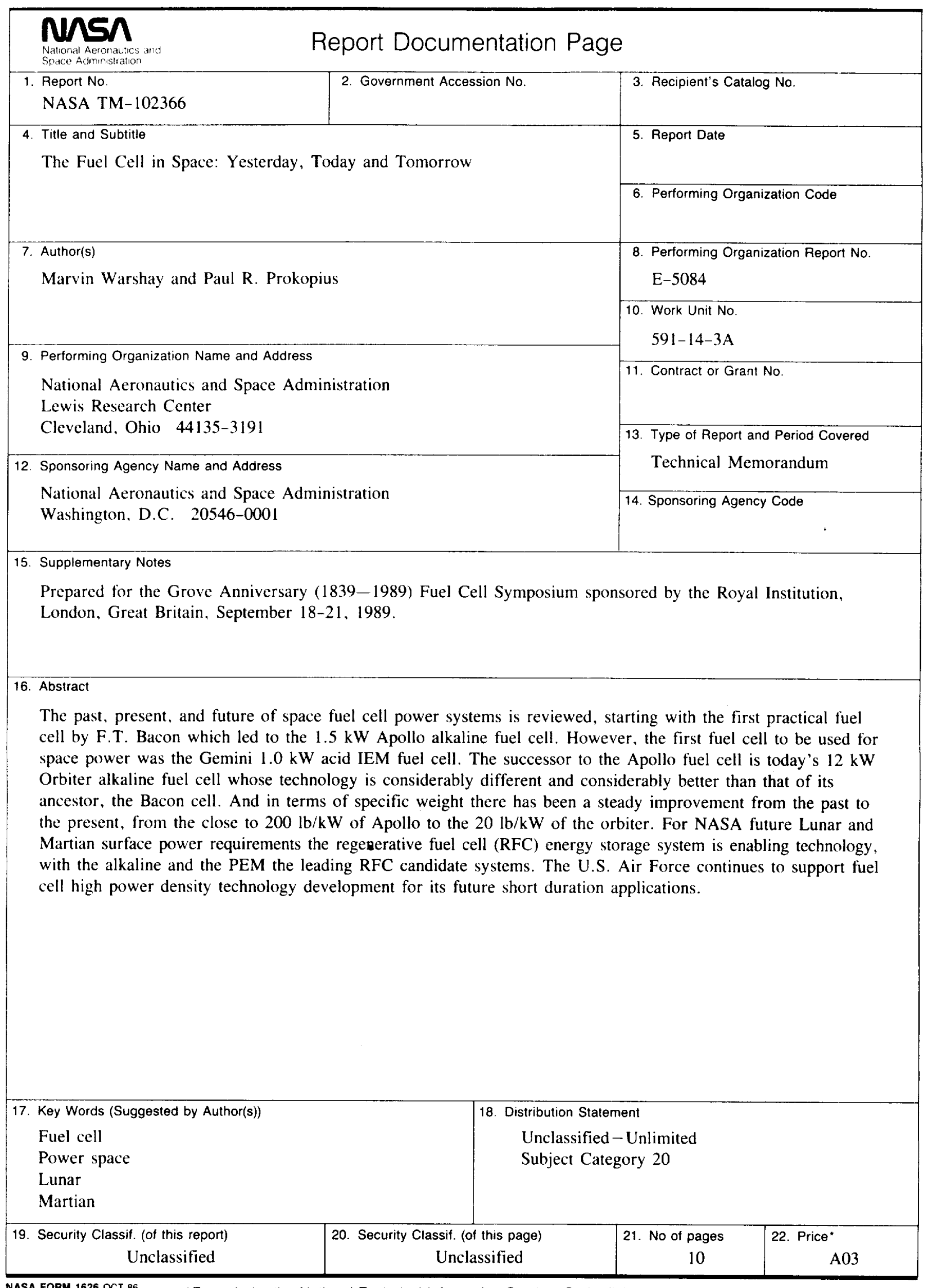

